\title{
RAZÕES DESSE ESCREVER
}

\author{
Maria do Amparo Rocha Caridade ${ }^{1}$ \\ REASONS FOR THIS WRITING
}

Resumo: Neste capítulo, questionamos sobre a necessidade de escrever sobre um tema, já por tantas vezes escrito, como o da sexualidade. Embora sem resposta para a indagação, sei que uma aflição interna em cada um de nós, que quer expressão, usa o ato de escrever, como uma das formas de domesticar o desassossego, que é existencial, mas também epistemológico.

Palavras-chave: Por que escrever?. Sexualidade. Aflição.

\begin{abstract}
In this chapter, we question the need to write about a topic already covered many times, such as sexuality. Although without answer to the above issue, I know that an internal distress in each person who wants to communicate, the act of writing is a way to tame our ansiety both existential and epistemological.
\end{abstract}

Keywords: Why write?. Sexuality. Distress.

"A escrita caminha como um corpo falante" Samira Chalhub

Penso que há, em cada pessoa, um livro a ser escrito, uma obra a e produzida, sobretudo, quando o tema em questão é a sexualidade. Neste sentido, seríamos todos potencialmente competentes para isso. Desde muito cedo fazemos descobertas, vivemos enamorados, intensas sensações, escrevemos poemas apaixonados, construímos uma bagagem de experiências amorosas que é singular, única, própria e inédita. Talvez por essa "competência básica" que existe em cada um e pelo direito e necessidade que se tem de expressá-la é que proliferem os discursos e os livros acerca da sexualidade. Haverá ainda o que dizer num momento histórico "em que o sexo parece ter feito seu completo strip-tease", como diz Jurandir Freire. Quanto a isso, ele mesmo considera que não há palavra final sobre o tema.

\footnotetext{
- Capítulo 1 do Livro - Sexualidade: corpo e metáfora. São Paulo: Iglu, 1997, p.17 - 21.

${ }^{1}$ Psicóloga Clínica, Mestre em Antropologia. Prof ${ }^{a}$. Adjunta da UNICAP - Recife, PE.
} 
Mas pergunto-me por que insistimos em escrever sobre o que já foi tantas vezes escrito? Por que nos esforçamos para dizer algo que outras pessoas o fizeram melhor que nós? Por que a inquietação, até que tentemos? Embora fique sem resposta a indagação, sei que uma aflição interna em cada um de nós, quer expressão e o ato de escrever é apenas uma das formas de domesticar esse "desassossego", que é existencial, mas também epistemológico. Cada indivíduo procura seu caminho. Pessoalmente, admiro e invejo os artistas plásticos, porque vejo, em cada obra feita, uma tarefa bem concluída, mesmo sabendo que para eles a obra está inacabada. A idéia de coisa acabada parece-me impossível ao escrever, mesmo que se tenha como resultado concreto um livro escrito. Essa tarefa interminável e insatisfatória caracteriza também a aflição de que falo. $\mathrm{O}$ ato de escrever apenas põe limites seja ao tema seja a inquietação existente.

As sensações de incompletude de uma obra são muito semelhantes ao que se pode dizer da sexualidade, como se ambas procedessem da mesma fonte energética e possuíssem as mesmas características de inquietação, busca e insatisfação. Tudo é muito inconcluso, mas é exatamente isso que nos faz tender pelo menos a uma aproximação da completude, do melhor, do mais perfeito.

Escrever é também um ato movido por uma pulsão catártica. A catarse torna-se possível quando se consegue encontrar imagens, expressões que digam (pelo menos parcialmente) do conteúdo que nos possui. Uma sedução perpassa essa busca da imagem que fale. "Por isso é que a verdade da sedução é quando o imaginar, que ela saturou por completo, estoura, precipita-se em sua própria encarnação e, de repente, anima-se com sua própria decomposição, transformando-se em criação viva, numa nova linguagem” (SBONY, 1991). Essa recriação, via decomposição e transformação da idéia, é o que seduz e o que confere ao texto algum valor e beleza.

O que tento transmitir neste ensaio já foi dito antes por tantos autores que me antecederam no gosto e no gozo de escrever sobre a sexualidade. Rigorosamente, nada é novo, teoricamente falando. Conforta-me imaginar que esse novo tão desejado acontece dinamicamente, isto é, algo é recriado e suscita no leitor um movimento talvez inesperado, mas numa via de mão dupla: o que foi escrito e a singularidade de codificação de quem o lê. Nessa interação, é possível a vitória do sentido. É isso que é novo.

A necessidade de escrever algo põe em exercício a sedução através da linguagem. Aí brincase com as palavras, descobrem-se novos sentidos, inventam-se emoções, tudo para embelezar 
o que é dito e para mobilizar no outro a emoção. Neste sentido, usa-se a palavra não só para se ser compreendido, mas também para se ser amado por esse leitor desconhecido que, talvez, jamais se chegue a conhecer. Coisa lamentável e interessante ao mesmo tempo, porque há um tom de mistério que é bom seja mantido nessa comunhão.

Toda essa sedução terá de satisfazer-se com a resposta silenciosa do leitor em suas reações pessoais ao texto. Resta o imaginário. A certeza de que uns se beneficiam, outros criticam, encantam-se, afinam-se ou não com as idéias é certeza imaginária. $\mathrm{O}$ contato é estabelecido via escrita. O desejo é a comunhão. Talvez menos, a generosidade da partilha intelectual, que é pequena, e mais, a ambição da grande comunhão com o outro o mais diverso possível. Vontade de pluralizar-se, de viajar por outros imaginários, ser cidadã desses imaginários.

Há tempo interesso-me pela questão da sexualidade. Trabalhei-a numa dissertação para o Mestrado em Antropologia na Universidade Federal de Pernambuco, em 1986, sob o título "Sexo, Mulher e Punição. A Sexualidade Feminina numa Instituição Penal". A partir de então passei a desenvolver outros trabalhos e a participar de diversos Congressos e eventos ocorridos no país, de modo que alguns dos temas aqui expostos já foram tratados nesses encontros e alguns destes inclusive publicados. Participo da SBRASH - Sociedade Brasileira de Sexualidade Humana, desde a sua criação, em 1989, por ocasião do primeiro Congresso Brasileiro no Rio de Janeiro. Aprendo muito por esses caminhos trilhados, pelas leituras e trabalhos desenvolvidos.

Particularmente aprendo e enriqueço-me com a escuta clínica, razão porque sou especialmente grata aos meus clientes. Tenho tido o privilégio de ouvi-los em suas dores e alegrias, acertos e desacertos, face aos projetos que têm de ser felizes. Talvez, por essa experiência de ouvi-los tenha produzido textos com a marca da intimidade. Tenho aprendido que o melhor que é vivido em termos sexuais carrega essa marca.

Trato simplesmente a sexualidade como isso que rodopia em nós, de mais corporal, mais simbólico e transcendente. Algo que viaja em nós via sentidos, exige satisfação, quer expressão e transcendência. Por isso, contextualizo-a em meio à vida dotada de significação. Postulo que não se perca de vista o encantamento, a paixão e o prazer como as mais belas expressões do ser sexual. São formas de comunicação-comunhão, de certo, perpassadas de mistério, assombro e tranqüilidade. A metáfora impõe-se para uma aproximação do inominável tão freqüente nessas experiências. "Mutilamos a realidade do amor quando a separamos de toda sua irrealidade”, penso como Bachelard (1988). A poesia será nesse 
terreno, mais eficiente que o discurso científico. A metáfora tem tanta força expressiva do mais íntimo que ela também pode nos consolar da ausência do outro, quando se dá a separação. Metaforizar a dor amorosa é especialmente catártico.

Postulo, ainda, que as indisposições sexuais que se apresentam em muitas pessoas têm algumas de suas raízes no obscurecimento das dimensões que são capazes de humanizar e tornar mais plena a experiência. A embriaguez do culto à performance imposta pelo efêmero, pelo veloz da época faz perder de vista a magia que se esconde no pormenor amoroso. Os gestos simples tornam-se imensos porque cheios de promessa encantada. Mas, o amante desatento não pode percebê-los.

Talvez, tudo isso pareça pouco afinado com as exigências da rapidez dos dias atuais. Sei, porém, que o gozo e o amor não têm pressa. A capacidade de "perder tempo" é condição necessária ao "encontrar o prazer" mais intenso. Algo de ingênuo perpassa o texto que talvez não pudesse ser diferente, pois penso que o que há de criativo e libertador na sexualidade desfaz-se das tramas da eficiência adulta e passa pela porção criança que subsiste em nós, promovendo êxtases indescritíveis e agonias inconsoláveis. A sexualidade é tudo isso e mais além que isso. Ela se situa no corpo, na experiência comum e também no extraordinário, como quem procura um ponto na experiência comum e também no extraordinário, como quem procura um ponto culminante.

\section{Referências bibliográficas}

BACHELARD, G. Poética do Devaneio. São Paulo, Martins Fontes, 1988.

FREIRE, J. apud COTONNÉ, P. A Sexualidade Ontem e Hoje. Cortez Ed.

SIBONY, D. Sedução. São Paulo, Brasiliense, 1991. 